\title{
Growth Performance of Khari Goats on Supplementation of Urea Molasses Mineral Block (UMMB) in Fodder Based Diets
}

\author{
M.R. Tiwari ${ }^{1}$, B.K. Shrestha ${ }^{2}$, P. Mandal $^{3}$ and L.N. Panday ${ }^{3}$ \\ ${ }^{1}$ National Animal Science Research Institute \\ Khumaltar, Lalitpur \\ ${ }^{2}$ Animal Nutrition Division \\ Khumaltar, Lalitpur \\ ${ }^{3}$ Sheep and Goat Research Programmee \\ Guthichaur, Jumla \\ e-mail: tiwari65@yahoo.com
}

\begin{abstract}
Goat is important component of Nepalese farming system. Goat production and productivity in Nepal is not as their potential. One of the major factors causing low production and productivity of goats is lack of minerals in the diet. Therefore, to evaluate the mineral factor associated with low production and productivity of goats an experiment was carried out in growing male goats at Agriculture Research Station (Goat), Bandipur, Tanahun from February to March 2010. Ten male goats of 8-9 months of age and similar body weight were divided into two treatment groups having five animals in each group by using complete randomized design (CRD). Two types of diets were formulated for experimental animals. The animals of control group (treatment1) were provided seasonal fodder ad libitum plus concentrate mixture @ 1\% of the body weight, whereas animals of treatment 2 were provided seasonal fodder and concentrate mixture same as in treatment1 plus UMMB @ 4\% of the body weight. The study revealed that seasonal fodder and concentrate mixture intake of both groups was almost similar $2.0 \mathrm{~kg}$ and $207 \mathrm{~g}$, respectively and was not significantly difference in intake between diet groups. Similarly, total dry matter intake also was non-significant between diet groups. The highest body weight gain was observed in treatment 2 (3.86 $\pm 0.78 \mathrm{~kg})$ than that of treatment1 $(3.3 \pm 0.90 \mathrm{~kg})$. Body weight gain of the experimental animals was also found non- significant. Average daily gain (ADG) was recorded the highest in treatment 2 (85.77 g/day) in comparison to treatment1 (73.33 g/day).
\end{abstract}

Key word: feeding trail,feed intake, urea molasses mineral block and body weight gain

\section{Introduction}

Goats are important component of Nepalese livestock, reared by small and marginal farmers. Goat population of Nepal is estimated to be 8.84 million and producing $50315 \mathrm{mt}$ meats per year (CBS 2010). Out of 8.84 million populations, Khari goat is the principle breed for population, and around 56 percent comes to this breed. This breed possesses better twinning ability among others. Furthermore, age at puberty and kidding interval of the Khari goat are comparatively shorter than any other indigenous goats (Pokharel \& Neopane 2006).
Goat production and productivity in Nepal is not as their potential. Several factors are responsible for low production and productivity of goats. One of the major factors is lack of minerals in the diet. However, mineral factor associated with production and productivity has not been properly addressed yet.

Urea-Molasses Mineral Blocks (UMMB) provides nitrogen over a longer period of time than any other urea sources. Molasses is a source of readily fermentable energy. Feeding UMMB can improve the utilization of roughages by satisfying the requirement 
of the rumen microorganisms creating a better environment for the fermentation of fibrous material and increasing production of microbial protein and volatile fatty acids. Urea is a product that after hydrolyzing into ammonia in the rumen can be used as a nitrogen source by the microbes (Anon 2008). The aim of the UMMB supplementation is to improve the utilization of low quality roughages, especially during dry season, when livestock are often solely dependent on crop residues or low quality dry season grazing, which are both low in crude protein and high in fibre. By considering, the mineral factor associated with low production and productivity of goats this experiment was initiated to evaluate the growth performance of growing goats supplemented with UMMB in fodder based diets.

Table 1. Experimental diet of the animal

\section{Methodology \\ Experimental animals}

This experiment was carried out in growing male goats at Agriculture Research Station (Goat), Bandipur, Tanahun from February to March 2010. Ten goats of average 8-9 months of age and similar body weight were divided into two treatment groups having five animals in each group by using a complete randomized design (CRD). They were drenched against internal parasites, vaccinated against infectious diseases, and were kept individually in wooden cage of $1 \times 1 \times 0.4 \mathrm{~m}$.

\section{Experimental diets}

The dry matter requirement of goats was calculated based on $4 \mathrm{~kg}$ per $100 \mathrm{~kg}$ body weight. Following diets were formulated to the experimental animals (Table 1).

\begin{tabular}{c|l|l}
\hline S/n & Treatment & Experimental diet \\
\hline 1 & $\begin{array}{l}\text { Treatment 1 } \\
\text { (Control) } \\
2\end{array}$ & $\begin{array}{l}\text { Seasonal fodder (ad libitum) + concentrate mixture @ 1\% of body weight } \\
\text { Treatment 2 }\end{array}$ \\
$\begin{array}{l}\text { Seasonal fodder (ad libitum) + concentrate mixture @ 1\% of body weight } \\
\text { + UMMB @ 4\% of body weight }\end{array}$ \\
\hline
\end{tabular}

\section{Feeding regime}

Seasonal fodder was provided to the goats individually thrice a day (morning, afternoon \& evening). Concentrate mixture and UMMB was mixed thoroughly and provided individually in plastic vessel once a day in the morning. Rate of concentrate mixture and UMMB was corrected fortnightly according to the body weight. Quantity of seasonal fodder and concentrate mixture given daily to the goats was weighed and refusal was weighed in the next morning. Drinking water was provided thrice a day in adequate amount. The concentrate mixture was used made by Pancharatna Feed Industry, Chitwan, whereas UMMB was used prepared by Animal Nutrition Division, Khumaltar, Lalitpur. The composition of UMMB was as given in Table 2 .

Table 2. Composition of UMMB

\begin{tabular}{ll}
\hline Ingredient & Percentage \\
\hline Urea & 10 \\
Molasses & 32 \\
Rice bran & 36 \\
Mineral & 6 \\
Salt & 5 \\
Cement & 5 \\
Calci oxide (choon) & 6 \\
\hline Total & $\mathbf{1 0 0}$ \\
\hline
\end{tabular}

\section{Chemical analysis}

The samples of seasonal fodder, concentrate mixture and UMMB was sent to the Animal Nutrition Division, Khumaltar, Lalitpur for proximate and detergent analysis. Representative samples were analyzed for dry matter (DM), crude protein (CP), crude fibre (CF), ether extract (EE) and total ash contents (TA). The $\mathrm{DM}$ was determined by oven drying at $100^{\circ} \mathrm{C}$ for 24 hrs. Crude protein of the samples was determined using the Kjeldahl method. Ether extract was determined using Soxhlet apparatus. Total ash content was determined by ashing at $550^{\circ} \mathrm{C}$ in a muffle furnace for 16 hrs (AOAC 1980). Crude fibre of the samples was determined using the Van Soest method (Goering, \& Van Soest 1970).

\section{Chemical composition of feedstuffs}

The result of chemical analysis is given in Table 3

\section{Measurement recording}

The trial period consisted 45 days after an adaptation period of 7 days. Total feed intake by the animals was recorded daily for the experimental period. The body weight gain of individual animal was taken at 15 days interval in the morning before feeding. 


\section{Data analysis}

Data of feed intake and body weight gain were analyzed by “t” test for every measurement using statistical package Minitab 2003, versions 13.20.

\section{Results and Discussion \\ Feed intake}

Average daily intake of seasonal fodder, concentrate mixture and UMMB by experimental animals is given in Table 4.

Table 3. Chemical composition of different feedstuffs (\% on DM basis)

\begin{tabular}{l|l|l|l|l|l|l}
\hline Ingredients & DM & OM & TA & CP & CF & Ca \\
\hline Seasonal fodder & 36.17 & 81.72 & 18.28 & 5.81 & 20.24 & 2.19 \\
Concentrate mixture & 85.96 & 88.87 & 11.13 & 16.13 & 11.49 \\
UMMB & 85.63 & NA & NA & 32.38 & 5.42 & 5.91 \\
\hline
\end{tabular}

$\mathrm{DM}=$ dry matter, $\mathrm{OM}=$ organic matter, $\mathrm{TA}=$ total ash, $\mathrm{CP}=$ crude protein, $\mathrm{CF}=$ crude fibre and $\mathrm{Ca}=$ calcium

Table 4. Feed intake of experimental animal/day

\begin{tabular}{l|l|l}
\hline Feedstuffs & \multicolumn{2}{|c}{ (Mean \pm SD) } \\
\hline & Treatment 1 & Treatment 2 \\
Seasonal fodder (kg) & $2.14 \pm 3.49$ & $2.23 \pm 2.77$ \\
Concentrate mixture, g & $207.25 \pm 0.04$ & $207.38 \pm 0.11$ \\
UMMB, g & - & $72.3 \pm 0.02$ \\
Total DMI / animal, kg & $42.67 \pm 1.27$ & $47.09 \pm 1.05$ \\
\hline
\end{tabular}

Average seasonal fodder intake of experimental animals per day was recorded $2.14 \pm 3.49 \mathrm{~kg}$ and $2.23 \pm$ $2.77 \mathrm{~kg}$ for treatment 1 and 2, respectively, whereas intake of concentrate mixture was $207.25 \pm 0.04 \mathrm{~g}$ and $207.38 \pm 0.11 \mathrm{~g}$, respectively. However, intake of seasonal fodder and concentrate mixture by animals was not significantly different between diet groups. The UMMB intake of experimental animals (treatment
2) was $72.3 \pm 0.02 \mathrm{~g}$ / day. In case of total DMI, treatment 2 consumed more DM $(47.09 \pm 1.05 \mathrm{~kg})$ than that of treatment 1 (42.67 $\pm 1.27 \mathrm{~kg})$; however, it did not significantly differ between diet groups.

\section{Growth performance}

The growth performance of experimental animals is given in Table 5 and Figure 1.

Table 5. Growth performance of goats

\begin{tabular}{l|l|l}
\hline \multirow{2}{*}{ Parameter } & \multicolumn{2}{|c}{ (Mean \pm SD) } \\
\cline { 2 - 3 } & Treatment 1 & Treatment 2 \\
\hline Initial body weight (kg) & $17.0 \pm 1.45$ & $16.8 \pm 2.65$ \\
Initial metabolic weight (kg) & 8.37 & 8.29 \\
Final body weight (kg) & $20.3 \pm 1.44$ & $20.66 \pm 2.89$ \\
Final metabolic weight (kg) & 9.56 & 9.69 \\
Total weight, gain (kg) & $3.3 \pm 0.90$ & $3.86 \pm 0.78$ \\
Changes in metabolic weight (kg) & 1.19 & 1.4 \\
Average daily gain (g) & 73.33 & 85.77 \\
Feed Conversion Ratio (FCR) (kg) & $12.93: 1$ & $12.19: 1$ \\
\hline
\end{tabular}

The average initial body weight of experimental animals were $17.0 \pm 1.45 \mathrm{~kg}$ and $16.8 \pm 2.65 \mathrm{~kg}$ and reached 20.3 $\pm 1.44 \mathrm{~kg}$ and $20.66 \pm 2.89 \mathrm{~kg}$, respectively for treatment 1 and 2 by the end of the experiment ( 45 days), however, initial and final body weights of goats was not differed significantly between diet groups. Highest body weight gain was observed in treatment 2 (3.86 \pm 0.78 $\mathrm{kg})$ than that of treatment $1(3.3 \pm 0.90 \mathrm{~kg})$. Average daily gain (ADG) was recorded highest in treatment 2 (85.77 g /day) in comparison to treatment 1 (73.33 g/ day). The feed conversion ratio (FCR) was higher for treatment $1(12.93: 1 \mathrm{~kg})$ while for treatment 2 it was $12.19: 1 \mathrm{~kg}$. 


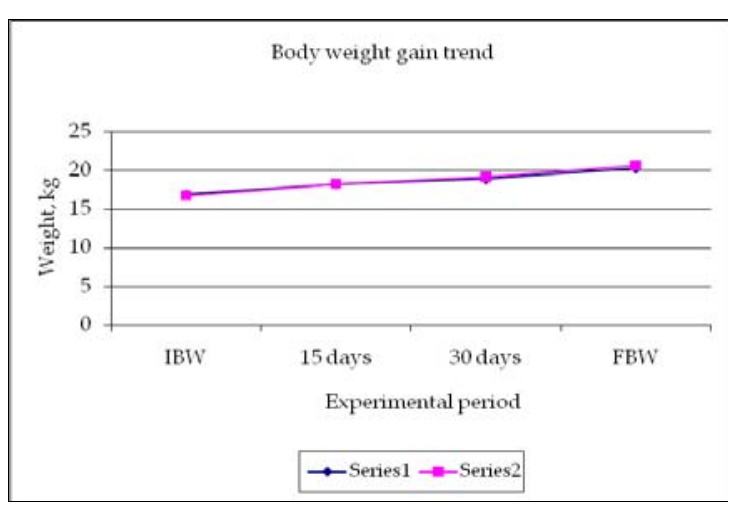

Fig.1. Growth performance of goats

The result of the study revealed that fodder and concentrate mixture intake of UMMB supplemented and non-supplemented group was almost $2.0 \mathrm{~kg}$ and $207 \mathrm{~g}$, respectively that was not significantly different between diet groups. Likewise, total DMI of both groups also was found non-significant. The highest body weight gain during 45 days of trial period was observed in treatment $2(3.86 \mathrm{~kg})$ than that of treatment 1 (3.3 kg) which was also found to be non- significant between diet groups. Average daily gain (ADG) was recorded highest in treatment 2 (85.77 g /day) supplemented with UMMB in comparison to treatment 1 (73.33 g/day).

Vargas and Riviera (1994) studied growth performance of growing sheep and showed that the provision of multi-nutritional block (10\% urea, 50\% molasses) ad libitum drastically reduced mortality in both ewes and lambs of African Hair breed. Furthermore, they reported that feeding of UMMB to ewes initiated early ovarian activity and shortened the interval from parturition to conception. Smallholder goat farmers can thus be encouraged to use UMMB for better animal performance

This experiment revealed that supplementation of UMMB in fodder-based diet of growing goats did not result significant effect on total DMI and growth performance between diet groups. Therefore, it is concluded that green fodder have sufficient minerals which can meet the animal requirement, however, it is suggested that similar type of experiments should be conducted on pregnant as well as lactating does to evaluate the effect of minerals on reproductive performance.

\section{Acknowledgements}

Our special thanks goes to Mr. Nar Bahadur Pulamai (Technical Helper) and Mr. Tek Bahadur Ale (Junior Technician) of Agriculture Research Station (Goat), Bandipur, Tanahun for their involvement in data recording, feeding and other management of experiment. We are also grateful to all other technical staff of the Station for their help during trial conduction. Similarly, we are thankful to all technical and administrative staff of Animal Nutrition Division, Khumaltar for their help in chemical analysis and other financial and technical matters.

\section{References}

AOAC. 1980. Official methods of analysis. 13th Association on analytical chemists, Washington D.C.

Anon. 2007/2008. Annual Report of Bovine Research Program, Khumaltar, Lalitpur.

CBS. 2009/10. Central Bureau of Statistics, National Planning Commission, Thapathali, Kathmandu, Nepal .

Goering, H.K and Van Soest 1970. Forage fibre analysis apparatus, reagents, procedures and some application, ARS, USDA Handbook No 397.

Pokharel, P.K and S.P Neopane 2006. Study on productivity improvement of hill goat through selective breeding programmee. Nepal Journal of Science and Technology, 7: 1-7.

Upreti, C.R and B.K Shrestha. 2010. Study on the effect of urea molasses mineral block (UMMB) supplementation on the milk production and infertility in dairy cattle in hill management system. Proceedings of the $9^{\text {th }}$ National Outreach Workshop, 7-8 June 2010, NARC, Kathmandu Pp 336-339.

Vargas, J.E and J.G Riviera 1994. Effecto del bloque multinutricional sobre el pottamiento productivo y reproductivo en ovejas africanas. Livestock Research for Rural Development 6:20-22. 